\title{
SERUM TRANSAMINASE LEVELS IN LIVER DISEASE
}

\author{
BY \\ L. HENRY \\ From the Department of Chemical Pathology, St. George's Hospital, London
}

(RECEIVED for PUblication august 2, 1958)

The process of transamination takes place in many tissues in the body and is a fundamental mechanism in the metabolism of amino-acids. Basically it consists of the reversible transfer of an amino group from an amino-acid to a keto acid, providing a link between protein and carbohydrate metabolism.

Although there appear to be a multitude of transamination systems, each catalysed by a specific enzyme, clinical interest centres on the following two reactions.
(1)<smiles>O=C(O)CCC(=O)O</smiles>

$\alpha$-Ketoglutaric Aspartic Acid Acid

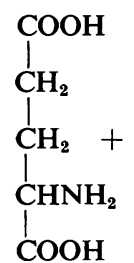

Glutamic Oxaloacetic Acid Acid

(2)<smiles>CC(N)C(=O)O</smiles>

$\alpha$-Ketoglutaric Alanine Acid

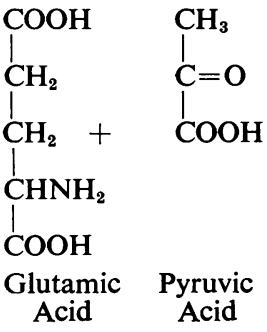

The first reaction is catalysed by glutamicoxaloacetic transaminase (GO-T) and the second by glutamic-pyruvic transaminase (GP-T). Measurements are usually made of the serum levels (SGO-T and SGP-T) of these enzymes.

It is presumed that the enzymes are liberated into the circulation during a period of cellular necrosis involving a tissue rich in transaminases. Cardiac muscle has a high content of GO-transaminase, and the high serum levels found in patients with myocardial infarction may be of value in the differential diagnosis of this condition. High levels have also been noted in acute hepatitis (Wróblewski, Jervis, and LaDue, 1956; Madson, Bang, and Iversen, 1958). In addition to its content of GO-T, the liver has a high concentration of GP-transaminase, and serum levels may also be raised in liver disease (Wróblewski and LaDue, 1956). Apart from a slight and inconstant rise in myocardial infarction (cardiac muscle contains much less GP-T than does the liver) these authors failed to detect a rise in SGP-T levels in the absence of liver disease. Therefore parallel determinations of SGO-T and SGP-T may prove to be a sensitive test of liver function. They may also be used as an aid in differential diagnosis, as the relative amounts of the two enzymes vary in differing forms of liver disease (Wróblewski, 1957).

The development of simple methods for the measurement of transaminases in serum has now brought such estimations within the range of the routine laboratory. The present survey was undertaken in order to assess the relationship between the SGO-T and SGP-T levels in patients with liver disease, and to compare these findings with the routine liver function tests.

\section{Methods}

Transaminase levels may be measured by incubation of the serum with substrate mixtures of $\alpha$-ketoglutaric acid and either aspartic acid or alanine. The amount of glutamic acid produced may be determined by quantitative chromatography (Karmen, Wróblewski, and LaDue, 1955), but the method is unsuited to routine work. A spectrophotometric method has been devised by these authors (Karmen, 1955 ; Wróblewski and LaDue, 1956) whereby the oxaloacetic or pyruvic acids formed are brought into a second enzyme system with reduced diphosphopyridine nucleotide. This reaction is catalysed by the addition of malic (for SGO-T) or lactic (for SGP-T) dehydrogenases with the formation of respectively malic and lactic acids. The rate of disappearance of the oxaloacetic or pyruvic acids is followed on a spectrophotometer. This method requires a suitable instrument and the provision of purified dehydrogenases, but has been used with success by Wróblewski and his colleagues 
and has been applied to routine use in Britain (Pryse-Davies and Wilkinson, 1958).

The SGO-T and SGP-T levels in this survey were estimated by a modification of the methods of Cabaud, Leeper, and Wróblewski (1956) and of Reitman and Frankel (1957) reported by Mohun and Cook (1957).

The oxaloacetic acid formed in the reaction is converted to pyruvic acid by aniline citrate. The addition of 2.4 dinitro-phenylhydrazine results in the formation of pyruvic phenylhydrazone which gives a reddish-brown colour when made alkaline.

This method seems to be ideally suited to routine use, as it is simple to perform and requires no special apparatus or reagents.

Measurements were made on a "unicam" S.P. 350 spectrophotometer at $505 \mathrm{~m} \mu$, but an EEL portable colorimeter may be used instead. As highly coloured or haemolysed serum may produce falsely high readings, a "serum blank" as recommended by Mohun and Cook (1957) was included in each estimation. The results were converted into the units proposed by Cabaud et al. (1956) by a calibration curve described by Mohun and Cook (1957). The upper limits of normal were taken to be 40 units $/ \mathrm{ml}$. for both SGO and SGP-T, and an analysis of 100 duplicate estimations showed a standard deviation of 3 units $/ \mathrm{ml}$. for levels below 300 units $/ \mathrm{ml}$. If levels of over 300 units $/ \mathrm{ml}$. were obtained the estimation was repeated using serum diluted with $M / 15$ Sorensen buffer of $p \mathrm{H} \mathrm{7.5.}$

The routine liver function tests performed were: Total serum bilirubin (upper limit $1.0 \mathrm{mg} . / 100 \mathrm{ml}$.), alkaline phosphatase (13 K-A units $/ 100 \mathrm{ml}$.), thymol turbidity ( 3 units), and thymol flocculation.

\section{Electropheretic Mobility}

Shepherd and McDonald (1958) reported that the SGO transaminase moved with the $\alpha_{2}$-globulin, and an attempt was made to separate the SGO and SGP enzymes on a basis of differing electrophoretic mobility on paper. In five cases of infective hepatitis the initial activity of the serum was high enough to enable this to be done.

Serum, $0.1 \mathrm{ml}$., was subjected to electrophoresis on $3 \mathrm{MM}$ Whatman paper and the run was performed in triplicate. When the albumin had moved about 3-4 in., two of the strips were cut into $\frac{1}{4}$ in. sections which were eluted into $\mathrm{M} / 15$ Sorensen buffer $p H 7.5$ and assayed for GO- and GP-T activity respectively. The third strip was stained to show the position of the protein fractions.

The results of two such estimations are shown in Fig. 1. In all five cases there was a clear-cut difference between the electrophoretic mobilities of the two enzymes. The GP-transaminase moves with or just behind the $\beta$-globulin while the GO-T moves with the $\alpha_{2}$-globulin or is intermediate in mobility between the $\alpha_{2^{-}}$and $\beta$-globulins. This confirms similar observations by Pryse-Davies and Wilkinson (1958).

\section{Results}

Specimens of blood passing through the laboratory for routine liver function tests were all examined for transaminase activity, and cases were noted where either or both of these were abnormal. In this way a total of 64 cases was selected, comprising 16 patients with acute hepatitis, 25 with obstructive jaundice, 17 with chronic liver disease, and six with hepatic metastases. The results of the routine liver function tests and transaminase estimations in each of these groups are shown in Tables I-IV.

Acute Hepatitis.-It is in this condition that the highest levels of transaminase activity are found. The liver has a high content of both enzymes, which are liberated during the phase of active hepatocellular damage. Examination of homogenates of liver from post-mortem specimens showed that the concentration of GP-T was greater than that of the GO enzyme (this result is in conflict with those of Wróblewski and LaDue (1956), who report less GP-T than GO-T in liver). Thus, in cases of acute hepatitis, the SGP-T level might be expected to exceed the SGO-T and this is in fact observed in all the cases examined.

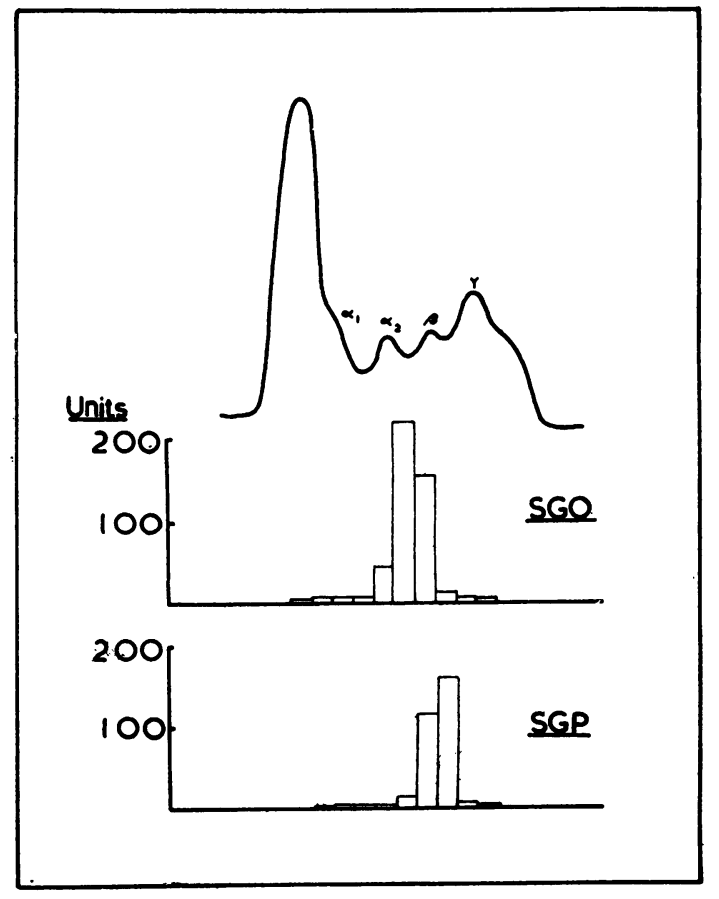

FIG. 1.-Case H.H. (Table I). Total SGO-T $=394$ units'ml. Total SGP-T $=1,500$ units $/ \mathrm{ml}$. 
TABLE I

SGO-T AND SGP-T LEVELS IN PATIENTS WITH ACUTE HEPATITIS

\begin{tabular}{|c|c|c|c|c|c|c|c|}
\hline Patient & $\begin{array}{l}\text { Days } \\
\text { from } \\
\text { Onset }\end{array}$ & $\begin{array}{c}\text { Bili- } \\
\text { rubin } \\
\text { (mg./ } \\
100 \mathrm{ml} .)\end{array}$ & $\begin{array}{c}\begin{array}{c}\text { Alka- } \\
\text { line } \\
\text { Phos- } \\
\text { phatase } \\
\text { (u./ } \\
100 \mathrm{ml} .)\end{array}\end{array}$ & $\begin{array}{c}\text { Thy- } \\
\text { mol } \\
\text { Turbid- } \\
\text { ity }\end{array}$ & $\begin{array}{l}\text { Thy- } \\
\text { mol } \\
\text { Floc- } \\
\text { cula- } \\
\text { tion }\end{array}$ & $\begin{array}{c}\text { SGO-T } \\
\text { (u. }(\mathrm{ml})\end{array}$ & $\begin{array}{l}\text { SGP-T } \\
\text { (u. } / \mathrm{ml} \text {.) }\end{array}$ \\
\hline \multirow[t]{4}{*}{ J.K. } & 1 & $2 \cdot 5$ & 19 & 7 & + & 460 & 2,060 \\
\hline & $\begin{array}{r}3 \\
15\end{array}$ & $\overline{1}$ & $\overline{272}$ & 5 & 一 & 500 & 1,760 \\
\hline & $\begin{array}{l}13 \\
23\end{array}$ & $\begin{array}{l}1.4 \\
0.5\end{array}$ & 18 & $\begin{array}{l}8.3 \\
6.3\end{array}$ & $\stackrel{+}{+}$ & $\begin{array}{l}30 \\
13\end{array}$ & $\begin{array}{r}200 \\
36\end{array}$ \\
\hline & 35 & 0.5 & 16 & 3 & Neg. & 15 & 25 \\
\hline \multirow[t]{5}{*}{ S.K. } & 2 & $\begin{array}{r}9.0 \\
10.2\end{array}$ & 15 & 2 & $"$ & 620 & 2,600 \\
\hline & $\begin{array}{r}0 \\
16\end{array}$ & $\begin{array}{r}10.2 \\
5.6\end{array}$ & $\begin{array}{l}10 \\
18\end{array}$ & $2 \cdot 5$ & ,", & $\begin{array}{l}1,000 \\
480\end{array}$ & 1,000 \\
\hline & 23 & $3 \cdot 1$ & 14 & 1.6 & ,", & 190 & 615 \\
\hline & 30 & 3.0 & 10 & 1.6 & ," & 38 & 114 \\
\hline & 37 & $1 \cdot 0$ & 12 & $1 \cdot 3$ & 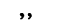 & 22 & 27 \\
\hline \multirow[t]{4}{*}{ B.R. } & 1 & - & - & - & - & Over & Over \\
\hline & 3 & 2.4 & - & - & - & 1,550 & 3,000 \\
\hline & 10 & $\begin{array}{l}6.8 \\
1.2\end{array}$ & 20 & 1 & Neg. & $\begin{array}{r}120 \\
19\end{array}$ & 420 \\
\hline & 40 & 1.0 & & & ", & 18 & \\
\hline D.B. & 7 & 9.0 & 22 & $5 \cdot 6$ & ," & 400 & 3,500 \\
\hline H.R. & 14 & 0.6 & 11 & 2 & , & 43 & 108 \\
\hline G.D. & 7 & $6 \cdot 3$ & $21 \cdot 5$ & 7 & + & 1,800 & 1,600 \\
\hline $\begin{array}{l}\text { H.H. } \\
\text { R.G. }\end{array}$ & 9 & $4 \cdot 5$ & 26 & $4 \cdot 7$ & Neg. & 394 & 1,500 \\
\hline $\begin{array}{l}\text { R.G. } \\
\text { D.M. }\end{array}$ & 8 & $\begin{array}{l}4.6 \\
4.1\end{array}$ & $\begin{array}{l}23 \\
31\end{array}$ & $\begin{array}{l}1.5 \\
1.5\end{array}$ & $"$ & 29 & $\begin{array}{r}53 \\
370\end{array}$ \\
\hline D.F. & 26 & 3.2 & 6.0 & 1 & ," & 10 & 9 \\
\hline J.P.R. & 50 & $2 \cdot 2$ & $13 \cdot 5$ & 1 & ," & 20 & 30 \\
\hline & 17 & 0.8 & 8 & 1 & ," & 27 & 89 \\
\hline $\begin{array}{l}\text { S.B. } \\
\text { C.A. }\end{array}$ & 3 & 1.4 & 10.5 & $2 \cdot 5$ & ," & 80 & 380 \\
\hline P.S.'. & 6 & 1.6 & 48 & 6 & $\ddot{+}$ & 110 & 350 \\
\hline & & & 19 & 5 & & 15 & 44 \\
\hline
\end{tabular}

* Acute hepatitis complicating glandular fever.

The serum levels of both enzymes will rise until the cellular necrosis is at its maximum and will thereafter fall to normal limits. The level at any particular time will therefore be governed $(a)$ by the amount of active necrosis causing a fresh release of enzyme, and $(b)$ by the normal processes of globulin metabolism which will remove the enzyme from the circulation. When the acute phase is over, only $(b)$ will operate, but if the liver damage continues an equilibrium will be attained and the serum level of the enzymes will remain elevated. This is presumably the case in patients with subacute hepatitis (Cases S. U., A.P., and G. S. in Table III).

In the cases shown in Figs. 2 and 3 the steady clinical improvement after the icteric phase and the gradual decline in the liver function tests to normal led us to postulate that the period of necrosis was not prolonged. The pattern of decline of the serum transaminase activity in these cases was of interest, as it afforded a measure of the rate of metabolism of the $\alpha$ - and $\beta$-globulins. If the levels are plotted against time on a semilogarithmic scale the rate of decay is approximately the same for both enzymes in each case. The survival time of the biologically active molecules lies between 11 and 24 days, and from the slope of degradation the half life is of the order of seven to 10 days. This is roughly in line with the existing estimate (Martin, 1957) of a half life of 10 days for pseudo-cholinesterase, another of the $\alpha_{2}$-globulins (Kekwick, 1955).

Fig. 4 shows the general relationship between the duration of the disease and the serum transaminase levels in 14 cases of acute hepatitis. In the two cases shown graphically (Figs. 2 and 3), there was a close correlation between the transaminase levels and routine liver function tests, but this was not so in every case. In two patients $(H . R$. and D. O., Table I), the routine tests were normal, but the raised transaminase levels presumably indicated that the period of activity of the disease had been prolonged, and in four cases (J. K., D. F., J. P. R., and B. R., Table I) the liver function tests were abnormal in the presence of normal transaminases. This makes it doubtful if the latter can be considered in isolation in assessing the progress of acute hepatitis. However, SGO-T determinations were used by O'Brien, Goble, and MacKay (1958) to assess the effectiveness of cortisone in chronic hepatitis. The findings in acute hepatitis complicating glandular fever are similar to those in infective hepatitis.

\section{TABLE II}

SGO-T AND SGP-T LEVELS IN PATIENTS WITH OBSTRUCTIVE JAUNDICE

\begin{tabular}{|c|c|c|c|c|c|c|}
\hline Patient & $\begin{array}{c}\text { Bili- } \\
\text { rubin } \\
\text { (mg./ } \\
100 \mathrm{ml} .)\end{array}$ & $\begin{array}{c}\text { Alka- } \\
\text { line } \\
\text { Phos- } \\
\text { phatase } \\
\text { (u./ } \\
100 \mathrm{ml} \text {.) }\end{array}$ & $\begin{array}{c}\text { Thymol } \\
\text { Turbid- } \\
\text { ity }\end{array}$ & $\begin{array}{c}\text { Thymol } \\
\text { Floc- } \\
\text { culation }\end{array}$ & $\begin{array}{l}\text { SGO-T } \\
(\mathrm{u} . / \mathrm{ml} .)\end{array}$ & $\begin{array}{c}\text { SGP-T } \\
\text { (u./ml.) }\end{array}$ \\
\hline $\begin{array}{l}\text { G.H. } \\
\text { A.F. } \\
\text { W.H. } \\
\text { A.D. } \\
\text { K.G. }\end{array}$ & $\begin{array}{r}13.0 \\
8.4 \\
1.0 \\
0.5 \\
11.4 \\
3.5\end{array}$ & $\begin{array}{l}30 \\
86 \\
46 \\
15 \\
38 \\
30\end{array}$ & $\begin{array}{l}1 \\
1 \\
1 \\
1 \\
1 \\
1 \cdot 2\end{array}$ & $\begin{array}{l}\text { Neg. } \\
\text {," } \\
\text {," } \\
\text {," }\end{array}$ & $\begin{array}{r}45 \\
64 \\
210 \\
66 \\
33 \\
107\end{array}$ & $\begin{array}{c}71 \\
300 \\
560 \\
300 \\
47 \\
\text { Over } \\
300\end{array}$ \\
\hline $\begin{array}{l}\text { E.S. } \\
\text { M.G. } \\
\text { F.C. } \\
\text { A.I. } \\
\text { E.H. } \\
\text { R.G. } \\
\text { S.N. } \\
\text { H.F. } \\
\text { J.B. } \\
\text { P.C. } \\
\text { M.M. } \\
\text { J.L. } \\
\text { S.W. } \\
\text { S.F. } \\
\text { N.W. } \\
\text { A.K. } \\
\text { B.P. } \\
\text { S.M.* } \\
\text { W.S.** } \\
\text { B.S.† }\end{array}$ & $\begin{array}{r}1.6 \\
17 \cdot 5 \\
1.9 \\
8 \cdot 5 \\
0 \cdot 5 \\
12.3 \\
2.8 \\
2.0 \\
0.5 \\
11 \cdot 5 \\
4.2 \\
1.7 \\
9.0 \\
1 \cdot 1 \\
099 \\
2.7 \\
3.6 \\
1.2 \\
3.2 \\
11.1\end{array}$ & $\begin{array}{l}16 \\
31 \cdot 5 \\
31 \cdot 5 \\
61 \\
23 \cdot 5 \\
34 \cdot 5 \\
65 \\
56 \\
18 \\
8 \cdot 5 \\
133 \\
83 \\
39 \\
22 \\
13 \cdot 5 \\
13 \cdot 5 \\
25 \\
18 \\
27 \\
39\end{array}$ & $\begin{array}{l}1 \cdot 2 \\
1 \cdot 5 \\
1 \\
1 \\
1 \\
1 \\
1 \\
1 \\
1 \\
1 \cdot 7 \\
1 \\
1 \cdot 5 \\
1 \\
1 \\
1 \\
1 \\
3 \cdot 8 \\
1 \\
1 \\
1 \cdot 5\end{array}$ & 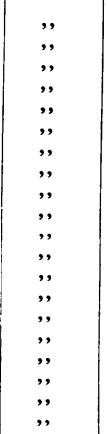 & $\begin{array}{r}60 \\
69 \\
80 \\
27 \\
24 \\
32 \\
46 \\
220 \\
48 \\
30 \\
62 \\
59 \\
2 \\
24 \\
470 \\
58 \\
140 \\
38 \\
111 \\
95\end{array}$ & $\begin{array}{r}83 \\
62 \\
120 \\
72 \\
13 \\
43 \\
48 \\
720 \\
112 \\
60 \\
102 \\
83 \\
6 \\
375 \\
990 \\
300 \\
360 \\
155 \\
200 \\
97\end{array}$ \\
\hline
\end{tabular}

* Cases of jaundice complicating chlorpromazine therapy. $\dagger$ Intrahepatic biliary obstruction. 

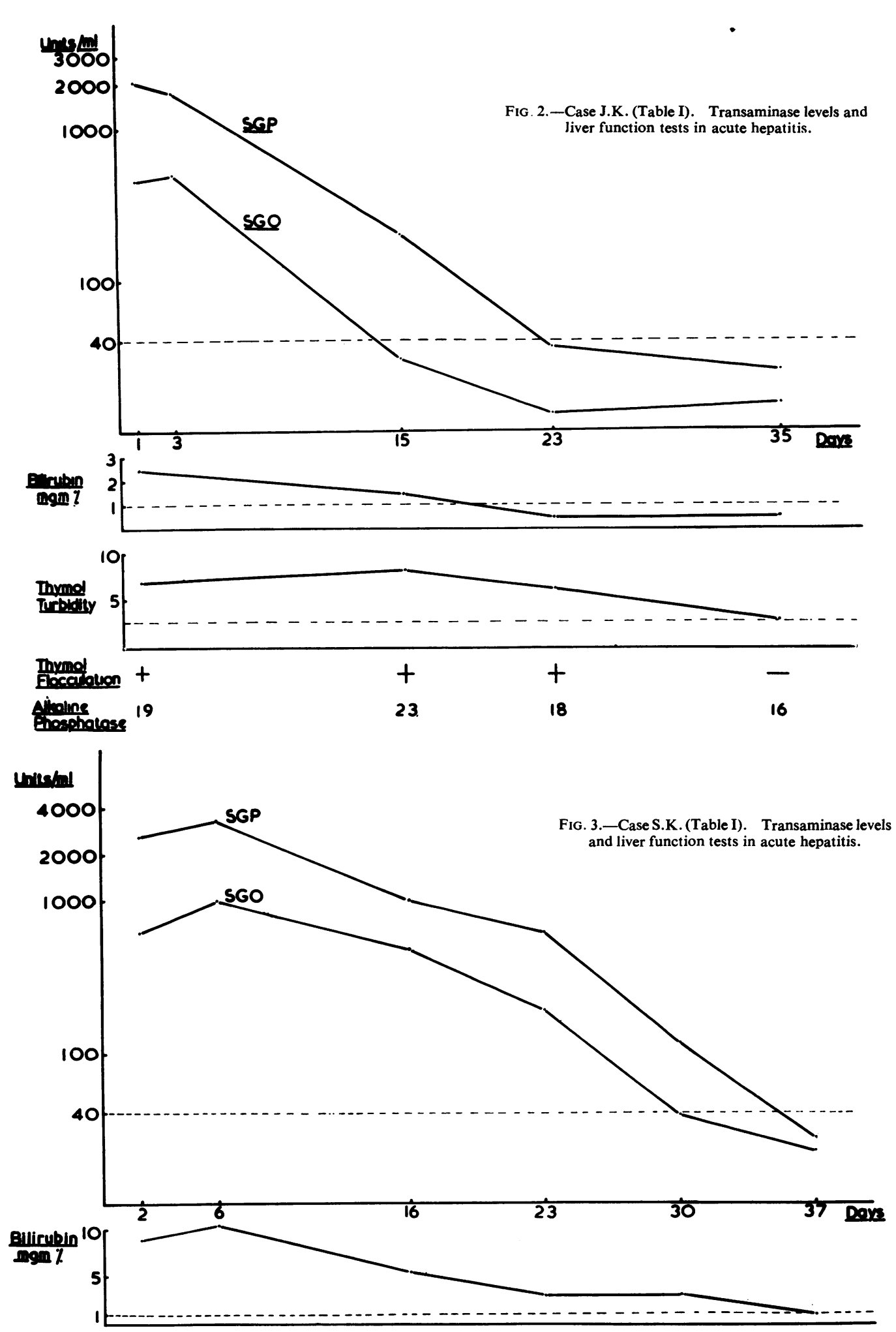

\begin{tabular}{|c|c|c|c|c|}
\hline Akring & 16 & 18 & 14 & 10 \\
\hline Thymol Turbenty 2 & 4.1 & 2.5 & 1.6 & 1.6 \\
\hline
\end{tabular}




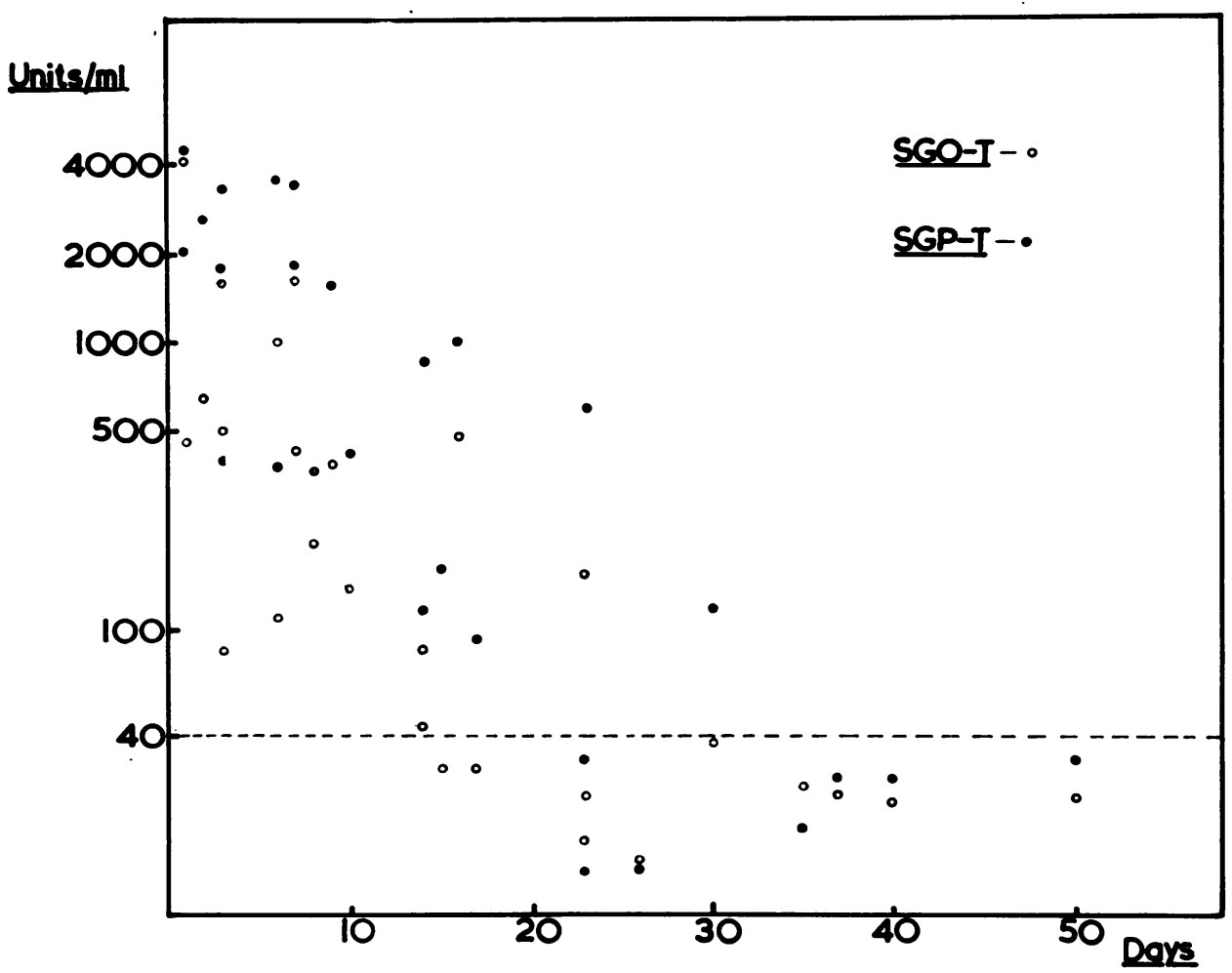

FIG. 4.-The relationship between the duration of the disease and the serum transaminase levels in 14 cases of acute hepatitis.

Obstructive Jaundice.-Twenty-five cases of obstructive jaundice were studied (Table II) and in only two cases (E. H. and S.W.) were the transaminase levels within normal limits. In all the other cases the SGP-T level was raised, this being associated with a smaller rise in SGO-T levels in 16 cases and a normal SGO-T level in the remaining six. In only one case (M. G.) did the SGO-T exceed the SGP-T level.

The liver function tests showed a constant pattern, namely, a raised bilirubin and alkaline phosphatase level with a normal thymol turbidity and flocculation reaction. The extent to which the transaminase levels were raised bore no constant relationship to the degree of abnormality of the routine tests. The one case $(\mathrm{N} . \mathrm{W}$.) in which these were normal showed extremely high transaminase levels and was judged clinically to have had an attack of biliary colic associated with gall stones.

The two cases of jaundice complicating largactil therapy are included in this group, as both the clinical and biochemical findings in such cases are similar to those in patients with extrahepatic biliary obstruction.
TABLE III

SGO-T AND SGP-T LEVELS IN PATIENTS WITH CHRONIC LIVER DISEASE

\begin{tabular}{|c|c|c|c|c|c|c|}
\hline Patient & $\begin{array}{c}\text { Bilirubin } \\
\text { (mg.! } \\
100 \mathrm{ml} .)\end{array}$ & $\begin{array}{c}\text { Alkaline } \\
\text { Phos- } \\
\text { phatase } \\
\text { (u./ } \\
100 \mathrm{ml} \text { ) }\end{array}$ & $\begin{array}{c}\text { Thymol } \\
\text { Turbid- } \\
\text { ity }\end{array}$ & $\begin{array}{c}\text { Thymol } \\
\text { Floc- } \\
\text { culation }\end{array}$ & $\begin{array}{r}\text { SGO-T } \\
\text { (u. } / \text { ml.) }\end{array}$ & $\begin{array}{c}\text { SGP-T } \\
\text { (u. } / \mathrm{ml} .)\end{array}$ \\
\hline $\begin{array}{l}\text { D.A.D. } \\
\text { J.S. } \\
\text { G.S.M. } \\
\text { L.H. } \\
\text { E.S. } \\
\text { L.P. } \\
\text { A.N. } \\
\text { C.O. } \\
\text { W.B. } \\
\text { G.A.S. } \\
\text { E.W. } \\
\text { G.A. } \\
\text { S.U.* } \\
\text { A.P.* } \\
\text { G.S.* } \\
\text { A.S.† } \\
\text { R.A.† }\end{array}$ & $\begin{array}{l}1.4 \\
1.8 \\
0.5 \\
1.4 \\
0.5 \\
0.5 \\
2.0 \\
0.6 \\
1.8 \\
3.4 \\
0.5 \\
0.5 \\
0.7 \\
1.6 \\
2.4 \\
2.6 \\
1.2\end{array}$ & $\begin{array}{l}12 \\
7 \cdot 5 \\
6 \\
18 \\
17 \\
13 \cdot 5 \\
24 \\
26 \cdot 5 \\
19 \cdot 5 \\
50 \\
12 \\
10 \\
7 \cdot 5 \\
13 \\
38 \\
11 \cdot 5 \\
11\end{array}$ & $\begin{array}{l}1 \\
3 \cdot 7 \\
1 \\
2 \\
1 \\
1 \cdot 5 \\
7 \\
1 \\
12 \\
3 \cdot 6 \\
1 \\
1 \cdot 2 \\
2 \cdot 5 \\
16 \\
3 \\
1 \\
9\end{array}$ & $\begin{array}{c}\text { Neg. } \\
\text { ", } \\
\text { ", } \\
\text { ", } \\
\stackrel{+}{+} \\
\text { Neg. } \\
+ \\
+ \\
\text { Neg. } \\
\text { ", } \\
+ \\
+ \\
\text { Neg. } \\
\text {, } \\
+\end{array}$ & $\begin{array}{r}43 \\
175 \\
44 \\
14 \\
40 \\
68 \\
67 \\
77 \\
110 \\
110 \\
47 \\
63 \\
41 \\
120 \\
73 \\
67 \\
115\end{array}$ & $\begin{array}{r}136 \\
44 \\
22 \\
5 \\
22 \\
63 \\
18 \\
21 \\
140 \\
113 \\
78 \\
54 \\
87 \\
170 \\
123 \\
152 \\
300\end{array}$ \\
\hline
\end{tabular}

* Subacute progressive hepatitis. † Acute-on-chronic hepatic disease.

Chronic Liver Disease.-The results are listed in Table III. The pattern of both the liver function tests and transaminase levels was variable. It would seem that in the subacute 
(Cases U. V., A.P., and G. S.) and acute-onchronic (Cases A.S. and R. A.) types both transaminases are raised, the SGP-T showing the greater increase. This would be consistent with a process of active liver cell damage. Of the 12 patients with established chronic liver damage, the serum levels of both enzymes were normal in two, the SGO-T was greater than SGP-T in five cases, the SGP-T being greater in the other five cases. There was no constant relationship to the routine tests, but a high thymol turbidity value seems often to be associated with a raised SGO-T level.

Secondary Carcinoma.-In these cases, the routine tests usually reveal a rise in the alkaline phosphatase level, and Table IV shows that in six cases with hepatic metastases this was a constant feature. In all cases the SGP-T level was raised and was higher than the SGO-T level in the four cases where this was also raised.

In patients with skeletal metastases the alkaline phosphatase may be raised, but the transaminase levels will be normal. In one such patient with secondary deposits in bone but none in the liver the alkaline phosphatase was 91 units/ $100 \mathrm{ml}$. and the SGO and SGP-T levels were 13 and 6 units $/ \mathrm{ml}$. respectively.

TABLE IV

SGO-T AND SGP-T LEVELS IN PATIENTS WITH HEPATIC METASTASES

\begin{tabular}{|c|c|c|c|c|c|c|}
\hline Patient & $\begin{array}{c}\text { Bilirubin } \\
\text { (mg./ } \\
100 \mathrm{ml} .)\end{array}$ & $\begin{array}{c}\text { Alkaline } \\
\text { Phos- } \\
\text { phatase } \\
\text { (u.l } \\
100 \mathrm{ml} \text {.) }\end{array}$ & $\begin{array}{c}\text { Thymol } \\
\text { Turbid- } \\
\text { ity }\end{array}$ & $\begin{array}{c}\text { Thymol } \\
\text { Floc- } \\
\text { culation }\end{array}$ & $\begin{array}{l}\text { SGO-T } \\
(\mathrm{u} . / \mathrm{ml} .)\end{array}$ & $\begin{array}{c}\text { SGP-T } \\
\text { (u./ml.) }\end{array}$ \\
\hline $\begin{array}{l}\text { H.M. } \\
\text { W.R. } \\
\text { J.G. } \\
\text { J.H. } \\
\text { C.A. } \\
\text { S.C. }\end{array}$ & $\begin{array}{l}6 \\
0 \cdot 5 \\
0 \cdot 5 \\
4 \cdot 2 \\
0 \cdot 9 \\
2 \cdot 3\end{array}$ & $\begin{array}{l}52 \\
27 \\
36 \\
35 \\
25 \\
46\end{array}$ & $\begin{array}{l}1 \\
1 \\
0 \cdot 8 \\
1 \\
1 \\
1\end{array}$ & $\begin{array}{l}\text { Neg. } \\
\text {," } \\
\text {," } \\
\text {,", }\end{array}$ & $\begin{array}{r}37 \\
45 \\
80 \\
35 \\
56 \\
200\end{array}$ & $\begin{array}{r}63 \\
62 \\
125 \\
97 \\
144 \\
560\end{array}$ \\
\hline
\end{tabular}

\section{Discussion}

The method of Mohun and Cook (1957) was found to work very well in practice and can be carried out easily in a routine laboratory. On the whole the results obtained agree with those of Wróblewski (1957) and Pryse-Davies and Wilkinson (1958) using the spectrophotometric method.

In acute hepatitis the high levels of transaminase in the serum make the estimations a very sensitive test of liver function, the SGP-T levels being higher than the SGO-T in the acute phase. Serial assays are useful in following the progress of the disease, but the levels may not necessarily be a more sensitive index than the routine tests. We would agree with Wróblewski (1957) when he states that transaminase estimations should not be considered in isolation but when taken in conjunction with other biochemical and clinical findings may prove to be of value. A persistently raised transaminase level will presumably indicate continuing liver cell damage.

In chronic liver disease the transaminases are not always abnormal, and where they are raised the relationships between the SGO-T and SGP-T levels are so variable that it is doubtful if any firm conclusions can be drawn from them. On the other hand in all his cases of cirrhosis Wróblewski (1957) found a constant rise in the SGO-T which always exceeded the SGP-T level.

The most consistent findings were in cases of obstructive jaundice where almost every case showed a rise in the SGP-T level over that of SGO-T. Pryse-Davies and Wilkinson (1958) found this ratio to be reversed in their series, but our results would confirm those of Wróblewski (1957), whose method was used by the latter authors. Unfortunately the estimations are of the least value in this group, as it is usually easy to diagnose extrahepatic obstructive jaundice on clinical grounds and by routine liver function tests.

In cases of secondary carcinoma we found the SGP-T levels to be consistently elevated, whereas Wróblewski (1957) reports a higher rise in SGO-T levels. However, the number of patients in our series is too small to allow any definite conclusions to be drawn.

\section{Summary}

Serum transaminase levels were estimated in 64 cases of liver disease and the results compared with the routine liver function tests. Particular attention was paid to the relation between the serum levels of glutamic-oxaloacetic transaminase and glutamic-pyruvic transaminase, and determinations of these were found to be a sensitive test of liver function.

The electrophoretic mobilities of the enzymes were confirmed, the GO-transaminase moving with the $\alpha_{2}$-globulin and the GP-transaminase with the $\beta$-globulin.

My thanks are due to Professor N. H. Martin for his advice and encouragement while carrying out this work.

I wish also to acknowledge financial assistance from St. George's Hospital Endowment Fund. 
REFERENCES

Cabaud. P., Leeper, R., and Wróblewski, F. (1956). Amer. J. clin. Path., 26, 1101.

Karmen, A. (1955). J. clin. Invest., 34, 131. Wróblewski, F., and LaDue, J. S. (1955). Ibid., 34, 126.

Kekwick, R. G. O. (1955). Thesis for Ph.D. London.

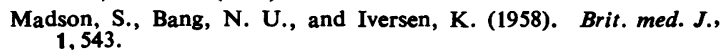

Martin, N. H. (1957). In Lectures on the Scientific Basis of Medicine, p. 169, 5. Athlone Press, London.
Mohun, A. F., and Cook, I. J. Y. (1957). J. clin. Path., 10, 394.

O'Brien, E. N., Goble, A. J., and MacKay, I. R. (1958). Lancet, 1, 1245.

Pryse-Davies, J., and Wilkinson, J. H. (1958). Ibid., 1, 1249.

Reitman, S., and Frankel, S. (1957). Amer. J. clin. Path., 28, 56.

Shepherd, H. G., and McDonald, H. J. (1958). Clin. Chem., 4, 13.

Wróblewski, F. (1957). A.M.A. Arch. intern. Med., 100, 635.

- and LaDue, J. S. (1956). Ann. intern. Med., 45, 801.

_ Jervis, G., and LaDue, J. S. (1956). Ibid., 45, 782. 